Predrag S. Kovačević ${ }^{1}$

University of Novi Sad

Faculty of Philosophy

Department of English Language and Literature

Novi Sad (Serbia)
UDC 316.723:78(497.11)"199/..." 78.067.26:316.75(497.11)"199/..."

Original scientific paper

Submitted 21/07/2018

Revised 22/10/2018

Accepted 11/10/2018

doi: $10.5937 /$ socpreg52-16767

\title{
BETWEEN THE FIRST AND THE SECOND SERBIA: ON THE POLITICAL AND CLASS DIMENSION OF HIP-HOP SUBCULTURE IN SERBIA ${ }^{2}$
}

\begin{abstract}
This paper tackles the phenomenon of hip-hop subculture in Serbia. The goal is to understand its development and to map out its class dimensions and political impulses. The analysis is grounded in cultural studies (cf. Hall, 1980). Hip-hop lyrics and symbolism of the hip-hop style are analyzed with a focus on political and class dimensions. The development of hip-hop subculture is divided into two phases. First, during the 1990s, the hip-hop subculture in the Serbian context was in the search for its local identity as a style that originated within the working-class but had its first representatives in Serbia among the middle-class youth. Hiphop's dialogue with the dizel culture during this period is indicative of this quest for identity. In the second phase, after 2000, hip-hop finds its place in the Serbian society by grounding itself in the working-class and establishing itself as the heir of the dizel subculture of the nineties (Papović and Pejović 2016). It also undergoes internal divisions producing an elitist wing further subdivided into a liberal and conservative part, and an anti-elitist wing with a chaotic political character hosting both radically leftwing and extreme right sentiments.
\end{abstract}

Keywords: hip-hop, subculture, elite, class, politics, transition.

\section{Introduction}

Twenty years ago hip-hop culture was recognized as a foreign influence in Serbia. However, today, the impact of hip-hop subculture has expanded, and it has become part of the mainstream culture. Even though hip-hop culture has had a big impact on the worldview and subcultural practices of many young people in Serbia, it has only recently been tackled in the academic literature (Papović and Pejović, 2016; Musić and Vukčević, 2017; and Đorđević, 2017).

1 pedjakovacevic90@gmail.com

2 The work on this paper was supported in part by the project No. 178002 of the Serbian Ministry of Science, Education and Technological Development. I would like to thank Professor Srđan Šljukić and Professor Marica Šljukić for providing very useful feedback on one of the earlier drafts. Dr. Andrew Hodges also read a later draft and made extensive comments which I benefited a lot from. It is doubtful if this paper would have existed without their help. 
In this paper, the goal is to analyze hip-hop culture in Serbia from the perspective of cultural studies (Hall 1980) and to explain how class divisions figure as important factors in the determination of the political impulses of the varieties of hip-hop subculture. The emphasis will be on the claim that class divisions inside hip-hop are an important factor in shaping the attitudes towards the legacy of the 1990s, i.e. the dizel subculture (see Papović and Pejović, 2016; Musić and Vukčević, 2017). It will be shown that parts of hip-hop subculture with negative attitudes towards the dizel subculture exhibit strong elitist tendencies either in the form of liberal elitism of the Second Serbia or conservative, nationalist elitism. The anti-elitist wing of the hip-hop scene, which identifies itself with the dizel subculture, does not have a clear political expression and oscillates between the far left and the far right.

\section{Cultural context: dizelaši and turbo folk?}

Dizeli or dizelaši are the Serbian children of neoliberalism (Papović and Pejović, 2016). The collapse of the welfare state in the West and the socialist systems in Eastern Europe gave birth to a different generation of working-class youth. Those generations acquired a materialistic outlook embodied in the desire for expensive clothes, cars and technical gadgets. The sense of collective belonging, which used to have a prominent national or class dimension in previous generations, now takes on a raw, tribal form of strong identification with a neighborhood crew, a hooligan band, or a gang (Maffesoli 1991). Subcultures that emerged under neoliberalism, from hip-hoppers in the US and British chavs to Russian gopniks and, of course, Serbian dizelaši, share many core features. Like American hip-hoppers, British chavs are known for their branded sports clothes, flashy jewelry, criminality and the total lack of respect for state institutions from police to education (Jones 2011). Russian gopniks also wear branded tracksuits and trainers while being prone to drinking and drug use (Gavrilyk, 2009).

Musić and Vukčević (2017) place Serbian dizelaši in this global context while pointing to their specific traits. Dizelaši appeared on the Serbian subcultural scene in the context of a civil war, transition and hyperinflation and amidst the formation of the networks of illegal economy intertwined with criminal circles. Fortunes were made overnight, but lives were lost even faster (Musić and Vukčević, 2017). The need to show off and the privileging of physical strength as opposed to intellectual abilities created a different kind of aesthetic embodied in muscular bodies, Eurodance rhythms, break dance, funk, and hip-hop. Eurodance finally provided some room for those who could not participate in the pettybourgeois rock'n'roll scene dominated by well-educated, middle-class youth (Matić, 2005).

Dizel culture contributed to the complex cultural mix because it became an urban counterpart of the supposedly rural subculture known as turbo folk. Turbo-folk of the nineties picked up on the tradition of Serbian folk music that had grown during the socialist era without the support of the state mostly in rural regions. However, during the 1990s, the political elite led by Slobodan Milošević recognized turbo folk as a powerful tool for consolidating the nationalist ideology (Gordy, 2010). The presence of turbo-folk created divisions on the cultural landscape of Serbia as it became a symbol of what the urban elite saw as an occupation by "the hordes from the hills" (Jansen, 2005). The urban culture dominated by rock and roll received an aura of cosmopolitanism and progressivism while 
turbo folk became the symbol of backwardness, violence, and bigotry reflecting the global Orientalist narrative (Simić 2010; Baker, 2008). The trouble with the dizel movement was that because of its urban origin and strong Eurodance influences it could not easily be squeezed into this binary urban/rural, elitist narrative.

Subcultures that emerged in the wake of the neoliberal turn all appear apolitical on the surface. However, their anti-elitism, inclination towards violence and the desire for expensive commodities created a new form of political protest in which violent behavior, shattered shop windows, and stolen Nike shoes supplanted any articulation of political demands. Žižek (2008) labeled this type of protest a phatic protest, i.e. an act whose main purpose is to signal the presence of a neglected group rather than articulate a demand.

\section{Early cultural history of Serbian hip-hop: the appropriation of the hip-hop expression}

Hip-hop is an art form that emerged in the English-speaking world, and consequently, the first fans of this music in Serbia were those young people who spoke English. In the socialist Yugoslavia, this fact alone often meant a middle class background (Vukčević, 2008). A genre that emerged as an artistic expression of the poor (Chang, 2005) had its first Serbian fans among the privileged, well-educated, upper-middle-class, urban youth.

The spread of hip-hop genre in Serbia coincided with the explosion of gangsta rap in the US and the division in hip-hop circles that it caused. Ambrozić (1994) presents this division to the Serbian public favoring the older politically-engaged current ${ }^{3}$. His claim was that hip-hop had the potential to mobilize the African Americans for social change but gangsta rap was counterproductive in that struggle. This stance echoed the position of many African American scholars who reacted to the appearance of gangsta rap in a similar way (see Ro 1996). Vukčević (2008) observes how this text was merely the introduction into a very intense debate about the role of hip-hop on the Serbian musical scene. In a radio show called Geto [Ghetto] on Radio Politika, a debate on gangsta rap took place around that time. One of the guests singled out the lack of education, violence, criminality, alcohol and drug use and a characteristic fashion style in order to compare gangsta rappers with the Serbian dizelaši, a new subcultural style emerging on the streets of Serbian cities (Vukčević, 2008). The lack of class awareness in the context of blocked transition during the 1990s (Bolčić, 2003) prevented him from seeing the clear class dimensions of this phenomenon. Of course, the comparison of gangsta rappers to dizelaši was accurate because the position of dizelaši in the distribution of economic and cultural capital in Serbia was similar to that of gangsta rappers in the US.

Despite this link between dizel subculture and hip-hop, this nascent intellectual hard-core of the hip-hop subculture in Serbia remained extremely hostile towards both dizelaši and gangsta hip-hop. Throughout the 1990s, the signifier hip-hoper was attached mostly to educated, urban groups of young people who listened to the music of American authors (Musić \& Vukčević, 2017).

\footnotetext{
3 Ambrozić was among the most prominent music critics of the 1980s and 1990s, who, according
} to Vukčević (2008), defended hip-hop from the harsh denunciations coming from rock critics. 
The denunciation of gangsta rap in America represented the resistance of the bourgeois cultural mainstream towards the discussion about all the elements of working-class existence (Dyson 1996). The pivotal issue was the fact that uneducated, poor and not particularly skillful singers and players of instruments suddenly called themselves musicians (Canton, 2006).

It is worth noting that already in the 1990s, some Serbian hip-hop artists gravitated towards gangsta rap, while some of them introduced elements of dizel subculture into their work. Therefore, during the entire final decade of the $20^{\text {th }}$ century, there existed a division between dedicated listeners and critics and a portion of hip-hop artists around the relationship towards dizelaši. The fact that immediately upon its inception in the Serbian context, hip-hop entered into a dialogue with the dizel subculture might also explain the instant popularity of some hip-hop bands and artists.

Sunshine is a band that was formed under the direct influence of gangsta rap (Janjatović, 2007). However, Sunshine is not a typical hip-hop band because its instrumentals are more akin to hard rock. Janjatović (2007) notes that popularity of Sunshine was mostly the result of their readiness to speak freely about the realities of life in Belgrade even though sometimes, the consequence was "unbearable lyrical pornography" (Janjatović, 2007: 283).

The band called Robin Hood identified the connection between gangsta rap and the dizel subculture and formed its style accordingly. Robin Hood articulates the thoughts of a dizel through the hip-hop expression ("Hip-hop as a Local Outlet", 2013). Robin Hood's landmark song, "Gangster", expresses the grudge against the establishment and the hypocrisy with which its members point a finger at dizelaši as the source of all social ills (Robin Hood, 2012). Robin Hood takes the side of open criminals as opposed to those who pretend to be upstanding citizens while looting the majority of the population.

The first phase in the history of Serbian hip-hop can be characterized as the struggle between the pioneering artists and the intellectual hard-core with a foot in the establishment. This fact supports Hebdidge's (1979) claim that struggle for the ownership over the signifier of a subculture is defined by class relations.

\section{Phase II: hip-hop as a mature cultural form in Serbia and an heir to dizel subculture}

After 2000, easier access to computer technologies enabled the expansion of hip-hop. The changes in the political discourse boiled down to the divisions regarding the issues of Serbian nationalism and social hierarchies which are typical dividing lines in contemporary capitalist societies (Bakić, 2015). The parties that emerged on the political landscape of Serbia could be easily categorized into the four quadrants formed by the intersection of the axes of nationalism and social hierarchy or elitism. There were anti-elitist (populist), nationalist parties like the Serbian Radical Party; elitist, nationalist parties such as the Serbian Democratic Party; elitist, internationalist parties like the Democratic Party and the Liberal Democratic Party, but the space for anti-elitist, anti-nationalistic forces remained empty throughout this period because anti-systemic leftist parties were never formed (Bakić, 2015). It became impossible to articulate a politics that would be internationalist and anti-elitist at the same time because that kind of politics usually presupposes a pronounced class mobilization and anti-capitalist goals.

The same kinds of divisions appeared in the sphere of culture as evidenced by the division between Gucha and Exit (Grabuschnig, 2015). Gucha became one of the most im- 
portant modern elements in the preservation of the Serbian national mythology because it cherishes the trumpet music and forms of entertainment characteristic of the rural Serbian setting (Kuligovski, 2011). Exit was initially a piece in a wide aresnal of tactics used by the Otpor movement in an effort to bring down Milošević. While there was significant popular support for the movement, there is no doubt that it was caught up in the elitist, pro-Western logic and as such favored and supported by Western governments and NGOs (Naumović, 2006). While the rock scene enthusiastically supported the demonstrations of the Otpor movement, folk stars remained committed to Gucha. Hip-hop had a certain connection with Exit, especially in the early 2000s because Exit enabled the Serbian audience to see megastars like Cypress Hill or Snoop Dog live. However, a large portion of the hip-hop audience also went to Gucha while many of them had no particular interest in either of these two festivals.

Another dividing line in the Serbian society collapsed together with Miloševićs regime. After 2000, tracksuits, Air Max trainers and Eurodance music disappeared from the streets and from the media. However, all these symbols were retained in the Serbian culture but they were prefixed by the aura of the nineties. The hip-hop subculture became the battleground of those same social and cultural divisions.

The dizel subculture represented an expression of the disenfranchised stratum of the urban working class that could find no place on the political scene of Serbia and Yugoslavia at least since 1970s (“Šta znači srpski nacionalizam”, 2011). With the disappearance of the dizel subculture as such after 2000, there was a demand for a new cultural expression that would speak in the name of this social stratum. Hip-hop appeared as the only candidate for that position, and all the divisions that appeared in hip-hop afterward can be interpreted as a chain reaction to the imposing presence of the dizel legacy.

In the remainder of this paper, it will be shown that the need to take a position towards the dizel culture or dizel legacy figured prominently in the formation of two currents within hip-hop, which are parallel to political and ideological divisions in the Serbian society after 2000 .

First, it is worth demonstrating how the landscape of the hip-hop subculture is easily mapped using the same coordinates that create divisions on the political scene in the first decade of the $21^{\text {st }}$ century. The crucial divisions on the political scene were the relationship towards the Serbian nationalism and the stance towards social hierarchy. This two-way division creates essentially four major political positions on the Serbian political spectrum. There are parties that could be described as nationalist liberal or nationalist elitist with an accompanying intellectual narrative that views the collapse of communism as a positive development for the Serbian nation. However, the argument is that Serbia finds itself under the rule of compradors and that it is faced with a moral decadence of a large portion of its young people who are influenced by the foreign, consumer media and decadent, domestic outlets like Pink TV (cf. Antonić, 2010, 2013, inter alia).

A large portion of the hip-hop scene in Serbia sees hip-hop as a way to articulate the stance of urban, patriotic young people against the corrupt political class loyal to the West. The best example is certainly Beogradski Sindikat (BS). This band consists of college-educated young people from middle-class neighborhoods in Belgrade, who also have successful careers as lawyers, economists, journalists, etc. Both in terms of the socio-economic background and in terms of its lyrics, BS represents the nationalistic, elitist outlook that is embodied by DSS on the political scene. 
The insistence on the need to revive the elite culture coming from conservative politicians manifests itself in the lyrics of BS via a link with the old cafe culture in Belgrade ${ }^{4}$. In the song titled "A Dissident's Ballad", one finds distinctive toponymic references, such as the café Zlatni Bokal [Golden Pot] on Skadarlija, are typical of BS, and they have a clear purpose to link the origins and works of this band with the elite locations in Belgrade (Beogradski Sindikat, 2012).

On the other hand, the lyrics of BS contain a clear stance towards the Serbian political elite loyal to the West. BS sees the ruling political elite as compradors or Western puppets who carry out policies in the interests of foreign multinationals and against the Serbian people. In the song titled "System is Lying to You", one of the main themes is the notion that the Serbian authorities are treading on their own people in the interests of foreign powers (Beogradski Sindikat, 2016).

BS is not immune to the traditional blood and soil metaphor of the far right. The songs of this band connect faith, the nation, the nation-state and the state territory into a supposedly natural whole. In "No One Can Know", the Serbian national idea is linked to the faith and the territory secured in wars, but the typical biological metaphors such as the connection between the land and the mother are also present (Beogradski Sindikat 2011).

BS has a distinctly negative stance towards the legacy of Yugoslav socialism, which they view as one of the causes of the present situation in the country. In "System is Lying to You", there is a description of the socialist system as a scam in which people were being fed an egalitarian ideology but the actual outcome was the enrichment of the party leadership (Beogradski Sindikat, 2016).

Like the Serbian political scene, hip-hop culture also has a prominent liberal wing. While their popularity is rather low at the moment, liberal forces are traditionally supported by a large part of the intellectual elite, the social stratum that is often called the Second Serbia (Čolović \& Mimica, 1992). Like the conservatives, the Second Serbia has its own ideological narrative. Given that their base is almost exclusively the upper-middle class, the Second Serbia exhibits explicitly elitist traits.

The exponents of the Second Serbia are profoundly aware of their lack of popularity and minority status, which is why the siege mentality and the feelings of being misunderstood or sabotaged by the backward masses play a crucial role in that narrative (see Perović, 2016a; 2016b). Despite the fact that the Second Serbia will often blame the masses for being obsessed with national myths, they rely on another set of myths that are rarely questioned and often taken as the final truth (Šljukić, 2011). The chief metaphor of the Second Serbia is one of the unwanted or fragile elite put forth by Latinka Perović (2016a; 2016 b; inter alia). She claims that the backward Serbian society blinded by egalitarianism, collectivism, and attachment to Russia, has always been hostile to rational, liberal, proWestern reformers; however, Bogdanović (2016) demonstrates how this view is closer to myth than to serious historiography.

It has already been argued that the hip-hop subculture entered Serbia through socio-economic circles that are quite close to the Second Serbia. However, after 2000, liberal stances have grown increasingly unpopular in hip-hop. For that reason, there are not many artists who could be uncontroversially classified as liberals, but there are a few figures

\footnotetext{
${ }^{4}$ More precisely, the café culture of Belgrade goes back to the Ottoman era and is different from similar tendencies in the West primarily because of its oriental overtones (see Hofman 2010).
} 
whose lyrics uphold the fundamental elements of liberal ideology. The common thread for all these artists is the liberal elitist stance towards the Serbian people who are depicted as politically and culturally dumbed down by national myths, folk music and the dizel culture.

One of the best examples of these tendencies is Marko Šelić better known as Marčelo. Like the members of BS, he also holds a university degree and he has published several novels and comics (Džodan, 2015). He quickly came to prominence owing to his lyrical capabilities. However, from the very beginning, many found his verbal flamboyance and eloquence arrogant. Marčelo's response has usually been to distance himself from such hip-hop fans often stating he does not consider himself a rapper (Džodan, 2015). These themes are rather prominent in a song titled "Testament" where he states that he is not a rapper and has nothing to do with the scene (Marčelo, 2008).

$\mathrm{He}$ is one of those rappers who frequently score easy points by making fun of dizels and those who listen to folk. The essential rightwing outlook that undercuts the liberal ideology is apparent in Marčelo's use of the same metaphor of illness that the nationalists use when they talk about dizel and folk subcultures. However, in his case, the metaphor of a virus or disease spreads beyond just those individuals who listen to folk. Marčelo (2013) also implies that all rappers share his disgust toward Eurodance.

In contrast to BS, which is trying to revive the mythology of the nationalistic, kafana elite, Marčelo presents himself as the heir of the avantgarde artistic elite gathered around rock'n'roll during the 70s and 80s. In the song "Pozerište", he concludes with a warning "if rock'n'roll is dead we are talking about a suicide!". The implication is that the abandonment of the rock'n'roll tradition entails the disappearance of any hope for a better future.

In Marčelo's songs, Serbian nationalism and political conservatism are also heavily criticized but from an urban universalist perspective (Simić, 2010). On his first album, in the song titled "Tears", he portrays nationalism as a backward ideology which brought nothing but bloodshed to the Balkans.

In opposition to these two currents in hip-hop subculture, there arises an anti-elitist face of hip-hop that sees itself as an heir to the dizel legacy. Lack of education, criminality, alcoholism, drug addiction and street smarts are among those traits that rappers belonging to this current find close to themselves. In political terms, most of them oscillate between the extreme right and the far left but the political constant for all of them is antielitism and anti-liberalism manifested in the idea of dizel lifestyle.

In 2002, a famous hip-hop band, VIP, released an album called The Crew is Here, which is usually considered a cornerstone of the next generation of hip-hop subculture (Vukčević, 2008). As Vukčević (2008) notes, the most important move that VIP made was to create a link between the Serbian identity, dizel identity and hip-hop identity. The Serbian identity as understood by VIP is essentially an angry reaction to the way working class, urban youth is treated by the newly established liberal elite. One of the two members of VIP, Ikac, released a very interesting song titled "Blown away into Pieces" where he delivered an emotional personal perspective decrying the conflicts of the 90 s without being accused of national betrayal and belonging to the Second Serbia (Ikac, 2010). These allegations are, however, regularly leveled against Marčelo and other rappers belonging to the elitist current.

Another rapper, Juice, went the furthest in his conscious reflection on the possibility of linking dizel subculture and other subcultural currents that existed in Belgrade but that have subsequently been divided by class. Juice understands that elitism was the decisive 
variable that permanently stigmatized dizel subculture thereby establishing lasting divisions among young people ("Juice vs Moskri” 2011).

Sometimes references to dizel culture are placed in the forefront and systematically emphasized, which is the case with Juice whose band is called $93 \mathrm{FU}$ where the number 93 is a reference to the year 1993 - the year of the infamous hyperinflation in Yugoslavia. His outfit always includes elements of dizel style such as tracksuits, gold chains, Nike trainers, etc. His lyrics are filled with metaphors and symbols of the 90s. The purpose behind this flashy and obnoxious style and image is mainly to distance himself from those "soft" and self-absorbed rappers who, in his words, "act like they are underground".

Bands like Prti Bee Gee, known for their explicit rhymes whose themes revolve around drugs, sex, and crime, most commonly signalize their belonging to dizel culture through frequent quotes from Eurodance hits, references to famous brands of shoes and clothes popular in the nineties and famous personalities from the dizel subculture. The band usually lambasts those public personalities that are known as symbols of false urban morality and elitism. The leader of the LDP, Čedomir Jovanović, is perhaps the most frequent target of critical and ironic comments of this band, underlining his connection with the criminal circles and hard drugs in contrast to his elitist public image.

When they talk about the members of the Skadarlija bohemian circles just like when they refer to the 80 s rock and roll stars, the members of Prti Bee Gee try to depict them as similar to themselves and the link is usually drug addiction or alcoholism. In one song, the late bandleader, Moskri, makes fun of the members of the band Električni Orgazam suggesting they are addicts like himself (Prti Bee Gee, 2012). In another song, he compares himself to Dragomir Bojanić Gidra, a legendary actor and bohemian, this time, based on shared alcohol addiction (Prti Bee Gee, 2013). Moskri's satire is often articulated with an egalitarian attitude by way of representing members of the elite as ordinary people often comparing them to himself.

Prti Bee Gee speaks about the realities of the daily lives of addicts who represent a growing part of the urban population. However, what is perhaps even more interesting is the way in which this band succeeded in opening up the space for the articulation of the voices of the Roma population. Liberal circles often insist on positive stereotypes when it comes to the Roma population such as their musical abilities. However, ever since Said's (2004) modern classic titled Orientalism, it is widely known that precisely these positive stereotypes represent a constitutive element of racism which works to legitimize the core of the racist logic. On the other hand, the truth of the matter is that crime, poverty, and addiction are part and parcel of the daily lives of most Roma people in Serbia.

A member of Prti Bee Gee, Nikola Jelić, better known by his alias Mikri Maus, who has a Roma family background, constantly invokes a parallelism between the African American population in the US and Roma people and dizelaši in Serbia. For Mikri Maus, the fact that Roma people often address each other using the word gypsy (in Serbian "cigan") is a direct counterpart of the word nigger used by African Americans 5 . His verses

\footnotetext{
${ }^{5}$ Kennedy (2008) tackles the attempt, mainly by white liberals, to legally prohibit the use of that word by black and white people alike. According to Kennedy (2008), for African Americans, this word represents a powerful political, cultural and historical link and a form of political mobilization at the symbolic level. The attempt by liberals to ban this word represents only one illustrative example of the project of universal pacification under the guise of political correctness.
} 
routinely include short, humorous anecdotes from the daily lives of the Roma people in the working class neighborhood of Medaković in Belgrade and the nearby partly informal neighborhood known as Marinkova Bara. Prti Bee Gee's lyrics make this lively social milieu closer to the rest of the urban society of Serbia. In the recent works of Prti Bee Gee and Mikri Maus's solo projects, references to the Roma people and dizelaši have become one of the main ways of undermining the dominant, elitist, liberal ideology (Mikri Maus, 2015).

What can be understood as leftist anti-elitism often coincides with the ideas of the extreme right on the same tracks. A good example of the extreme rightwing vision of hiphop as an heir of the dizel culture is a young rapper known as Marlon Brutal. His ideology and rhetoric are well-illustrated in the song titled "Boulevard of Violence". His verse in this song represents a powerful description of the atmosphere in the working class neighborhoods of Belgrade where the smell of marijuana and violence are integral parts of one's childhood and adolescence (THCF \& Marlon Brutal, 2009). The basic ideological line is one of unconditional solidarity with the "homies" and a deep hatred towards everyone who does not belong to that social milieu - people from other neighborhoods or other cities, fans of different sports clubs or people from other countries. It is important to note that dizel culture and folk music figure as the defining cultural feature because belonging to the working class culture as opposed to elite culture is the centerpiece of the neighborhood identity.

Even though Marlon Brutal considers light and synthetic drugs to be part and parcel of what constitutes the everyday life of the neighborhood, he expresses violent hatred towards hard drugs. In the rightwing circles where physical strength and ability to engage in violence are of great importance, hard drugs are almost always seen as an evil and drug users are seen as human parasites.

Anti-elitist rappers often joke about or outright insult rappers from the elitist (liberal and nationalist) part of the hip-hop scene while the reverse is rarely the case. Bands like Prti Bee Gee are virtually untouchable for critique at least among the more committed fans of hip-hop despite their glorification of crime and addiction, which is often criticized by people outside of the hip-hop circles. Their status became even more entrenched after the death of their most prominent member, Moskri, who became a mythic figure on the hip-hop scene and is often compared to the legendary Tupac Shakur (see Keeling 1999 on the mythic status of Tupac Shakur).

\section{Conclusion}

By way of conclusion, it should be said that the meaning of class divisions inside hiphop subculture was analyzed in the context of the rise of the extreme right and the weakness of the radical left in present-day Serbia as described by Bakić (2015) among many others. The outcome of this volatile situation will depend crucially on the general political climate and perhaps the ability of the leftwing forces to overcome the academism, elitism, and intellectualism that currently defines the majority of leftwing organizations. 
Предраг С. Ковачевић, Између Прве и Друге Србије: о политичкој и класној...

Предраг С. Ковачевић ${ }^{1}$

Универзитет у Новом Саду

Филозофски факултет

Одсек за англистику

Нови Сад (Србија)

\title{
ИЗМЕЂУ ПРВЕ И ДРУГЕ СРБИЈЕ: О ПОЛИТИЧКОЈ И КЛАСНОЈ ДИМЕНЗИЈИ ХИП-ХОП СУПКУЛТУРЕ У СРБИЈИ
}

\author{
(Превоg In Extenso)
}

Сажетак Рад се бави проблематиком хип-хоп супкултуре у Србији. Циљ рада је разумевање њеног настанка и развоја као и мапирање њене политичке композиције. Анализа се заснива на студијама културе као теоријско-методолошком оквиру (Hall, 1980). Хип-хоп поезија и симболичка значења препознатљивих елемената ове супкултуре анализирају се с посебним освртом на класне и политичке димензије. Развој хип-хоп супкултуре подељен је у две фазе. Прва је током деведесетих, када новонастала хип-хоп супкултура у Србији трага за својим аутентичним, локалним карактером, као стил који је настао међу радничком класом, а прве поборнике у Србији нашао међу средњом класом. Односом хип-хопа и дизел-културе у том периоду илуструје се ова потрага за идентитетом. У другој фази, хип-хоп коначно проналази своје место у српском друштву тиме што се учвршћује у радничкој класи и повезује са дизел културом нарочито након повратка дизелаштва (Papović \& Pejović, 2016). У том процесу, хип-хоп супкултура се дели на елитистичко крило, даље подељено на либерални и конзервативни део, и антиелитистичко крило са хаотичним политичким карактером који осцилује од радикално левих до екстремно десних ставова.

Кључне речи: хип-хоп, супкултура, елита, класа, политика, транзиција.

\section{1. Увод}

Пре двадесет година хип-хоп култура препозната је као инострани утицај у Србији. Међутим, данас се утицај хип-хоп супкултуре повећао и постао део главне

1 pedjakovacevic90@gmail.com

2 Рад на овом чланку је делимично подржан пројектом Министарства науке, образовања и технолошког развоја Републике Србије број 178002. Желео бих да се захвалим професору Срђану Шљукићу и професору Марици Шљукићу за пружање веома корисних повратних информација о једном од ранијих нацрта. Др Andrew Hodges такође је прочитао каснији нацрт и направио обимне коментаре од којих сам много користио. Неизвесно је да ли би овај рад постојао без њихове помоћи. 
културе. Иако хип-хоп култура има велики утицај на поглед на свет и супкултурне праксе многих младих људи у Србији, академска литература је њоме недавно почела да се бави (Papović \& Pejović, 2016; Musić \& Vukčević, 2017; Đorđević, 2017).

У овом раду, циљ је да се направи анализа хип-хоп културе у Србији из перспективе културних студија (Hall, 1980) и да се објасни како класне поделе фигурирају као важни фактори у одређивању политичких импулса различитих хип-хоп супкултура. Нагласак ће бити на тврдњи да су класне поделе унутар хип-хопа важан фактор у обликовању ставова према наслеђу из деведесетих година, тј. према дизел- супкултури (види Papović \& Pejović, 2016; Musić \& Vukčević, 2017). Показаће се да делови хип-хоп супкултуре са негативним ставом према дизел супкултури показују јаке елитистичке тенденције, било у облику либералног елитизма Друіе Србије или конзервативног, националистичког елитизма. Антиелитистичко крило хип-хоп сцене, које се идентификује са дизел-супкултуром, нема јасан политички израз и осцилира између крајње левице и крајње деснице.

\section{2. Културни контекст: gизелаши и турбофолк?}

Дизели или gизелаши су српска деца неолиберализма (Papović \& Pejović, 2016). Пропаст државе благостања на Западу и социјалистичких система у Источној Европи родила је другу генерацију младих из радничке класе. Те генерације су стекле материјалистичке ставове утеловљене у жељи за скупом одећом, аутомобилима и техничким уређајима. Осећај колективне припадности, који је у претходним генерацијама имао истакнуту националну или класну димензију, сада узима сирову, племенску форму снажне идентификације са екипом из краја, групом хулигана или бандом (Maffesoli, 1991). Супкултуре које су се појавиле под неолиберализмом, од хий-хойера у Америци, преко чевса у Британији до руских іойника и, наравно, српских gизелаша, деле многе основ-

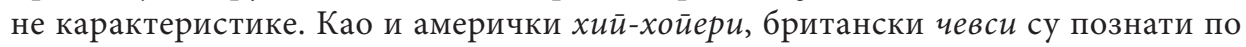
својој брендираној спортској одећи, блиставом накиту, криминалитету и тоталном недостатку поштовања државних институција од полиције до образовања (Jones, 2011). Руски їойници такође носе брендиране тренерке и патике, склони су пићу и употреби дрога (Gavrilyk, 2009).

Мусић и Вукчевић (2017) постављају српске gизелаше у овај глобални контекст, указујући на њихове специфичне особине. Дизелаши су се појавили на српској супкултурној сцени у контексту грађанског рата, транзиције, хиперинфлације и успостављања мреже нелегалне економије испреплетане криминалним круговима. Богатства су стицана преко ноћи, а животи губљени још брже (Musić \& Vukčević, 2017). Потреба да се покаже пред другима и фаворизовање физичке снаге у односу на интелектуалне способности створило је другачију врсту естетике садржане у мишићавим телима, ритмици евроденса, брејкденсу, фанку и хип-хопу. Евроденс је коначно обезбедио простор за оне који нису могли да учествују на ситнобуржоаској рокенрол сцени у којој доминира добро образована омладина из средње класе (Matić, 2005).

Дизел-култура допринела је сложеној културној мешавини, јер је постала урбана супротност наводно руралној супкултури познатој под називом турбофолк. Турбо- 
Предраг С. Ковачевић, Између Прве и Друге Србије: о политичкој и класној...

фолк из деведесетих година се наставио на традицију српске народне музике која је напредовала у социјалистичкој ери без подршке државе углавном у руралним регионима. Међутим, током деведесетих година, политичка елита коју је предводио Слободан Милошевић препознала је турбофолк као моћно средство за консолидацију националистичке идеологије (Gordy, 2010). Присуство турбофолка створило је поделе на културном пејзажу Србије, јер је постало симбол онога што је урбана елита видела као окупацију оних који су „сишли с’ брда“ (Jansen, 2005). Урбана култура у којој доминира рокенрол добила је ауру космополитизма и прогресивизма, док је турбофолк постао симбол заосталости, насиља и биготизма који одражавају глобални оријенталистички наратив (Simić 2010; Baker, 2008). Проблем са дизел-покретом је био тај што га због свог урбаног порекла и јаких утицаја евроденса није било лако потиснути у овај бинарни урбано/рурални елитистички наратив.

Супкултуре које су се појавиле уочи неолибералног преокрета деловале су као аполитичне на површини. Међутим, њихов антиелитизам, склоност ка насиљу и жеља за скупом робом, створили су нови облик политичког протеста у којем су насилно понашање, разбијени излози и украдене Nike патике заменили било какву артикулацију политичких захтева. Ову врсту протеста Жижек (2008) означио је

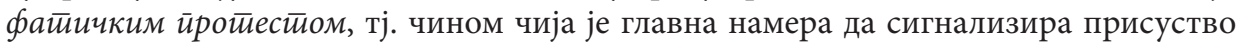
запуштене групе уместо да артикулише потражњу.

\section{3. Рана културна историја српског хип-хопа: апропријација експресије хип-хопа}

Хип-хоп је уметничка форма која се појавила на енглеском говорном подручју, па су, према томе, први љубитељи ове музике у Србији били млади људи који су говорили енглески језик. У социјалистичкој Југославији, ова чињеница сама по себи често је значила средњу класу (Vukčević, 2008). Жанр који се појавио као уметнички израз сиромашних (Chang, 2005) имао је своје прве фанове у Србији међу привилегованом, добро образованом, урбаном омладином из средње класе.

Ширење хип-хоп жанра у Србији поклопило се са експлозијом гангста-репа у САД и поделом у хип-хоп круговима. Амброзић (1994) представља ову поделу српској јавности фаворизујући старије политички ангажоване струје ${ }^{3}$. Његова тврдња била је да је хип-хоп имао потенцијал да мобилише Афроамериканце за друштвене промене, а гангста-реп је био контрапродуктиван у тој борби. Овај став поновио је тврдње многих афроамеричких научника који су на сличан начин реаговали на појаву гангста-репа (в. Ro, 1996). Вукчевић (2008) примећуjе како је овај текст само увод у врло интензивну дебату о улози хип-хопа на српској музичкој сцени. У радио-емисији под називом Гетио на Радију “Политика“ одржана је дебата о гангста-репу, отприлике, у то време. Један од гостију издвојио је недостатак образовања, насиље, криминалитет, употребу алкохола и дроге, карактеристичан модни стил, како би упоредио гангста-репере са српским gизелашима, новим супкултурним стилом који се појављује на улицама српских градова (Vukčević, 2008).

3 Амброзић је био међу најистакнутијим музичким критичарима осамдесетих и деведесетих година прошлог века, који је, према Вукчевићу (2008), одбранио хип-хоп од жестоке осуде рок критичара. 
Недостатак класне освешћености у контексту блокиране йранзииије током деведесетих година (Bolčić, 2003) спречио га је да види јасне класне димензије ове појаве. Наравно, поређење гангста-репера са gизелашима било је тачно, јер је положај guзелаша у дистрибуцији привредног и културног капитала у Србији сличан оном код гангста-репера у Сједињеним Државама.

Упркос овој вези између дизел супкултуре и хип-хопа, настало интелектуално језгро хип-хоп супкултуре у Србији остало је изузетно непријатељски расположено и према gизелашима и према гангста хип-хопу. Током деведесетих година, хип-хоперима су се означавале углавном образоване, урбане групе младих људи који су слушали музику америчких аутора (Musić \& Vukčević, 2017).

Осуда гангста-репа у Америци представљала је отпор буржоаског културног мејнстрима ка дискусији о свим елементима постојања радничке класе (Dison, 1996). Кључно питање била је чињеница да су необразовани, сиромашни и не посебно вешти певачи и свирачи инструмената изненада назвали себе музичарима (Canton, 2006).

Важно је напоменути да су већ деведесетих година неки српски хип-хоп уметници гравитирали ка гангста-репу, док су неки од њих у свој рад увели елементе дизел-супкултуре. Дакле, током целе последње деценије двадесетог века постојала је подела међу посвећеним слушаоцима, критичарима и хип-хоп уметницима око односа према gизелашима. Сама чињеница да је одмах по свом настанку у српском контексту хип-хоп ушао у дијалог са дизел-супкултуром, такође може објаснити тренутну популарност неких хип-хоп бендова и уметника.

Саншајн је бенд који је настао под директним утицајем гангста-репа (Janjatović, 2007). Међутим, Саншајн није типичан хип-хоп бенд, јер су његови инструменти сличнији хард року. Јањатовић (2007) примећује да је популарност Саншајна углавном резултат њихове спремности да слободно говоре о стварности живота у Београду, иако је понекад последица била „неподношљива лирска порнографија“ (Janjatović, 2007, str. 283).

Група звана Robin Hood идентификовала је везу између гангста-репа и дизел- -супкултуре и формирала свој стил у складу с тим. Robin Hood артикулише мисли о guзeташйву кроз хип-хоп израз (Hip-hop as a Local Outlet, 2013). Најпознатија пе-сма групе Robin Hood, „Гангстер“, изражава незадовољство системом и лицемерјем с којим његови чланови упиру прст ка gизелашима као извору свих друштвених болести (Robin Hood, 2012). Robin Hood стаје на страну отворених злочинаца, насупрот онима који се претварају да су узорни грађани истовремено пљачкајући већину становништва.

Прва фаза у историји српског хип-хопа може се окарактерисати као борба између пионирских уметника и интелектуалног језгра које једном ногом стоји у систему. Ова чињеница подржава Хебдигеову (1979) тврдњу да је борба за власништво над означитељем супкултуре дефинисана класним односима.

\section{4. Фаза друга: хип-хоп као зрео културни облик у Србији и наследник дизел-супкултуре}

Након 2000. године, лакши приступ рачунарским технологијама, омогућио је експанзију хип-хопа. Промене у политичком дискурсу сводиле су се на поделе у 
Предраг С. Ковачевић, Између Прве и Друге Србије: о политичкој и класној...

вези с питањима српског национализма и друштвених хијерархија које су типичне линије раздвајања у савременим капиталистичким друштвима (Bakić, 2015). Странке које су се појавиле на политичком пејзажу Србије могле су се лако категорисати у четири квадранта формирана пресеком оса национализма и друштвене хијерархије или елитизма. Постојале су антиелитистичке (популистичке) националистичке партије попут Српске радикалне странке; елитистичке националистичке странке као што је Српска демократска странка; елитистичке интернационалистичке партије као што су Демократска странка и Либерално-демократска партија, али је простор за антиелитистичке антинационалистичке снаге остао празан током овог периода, јер антисистемске левичарске странке никада нису биле формиране (Bakić, 2015). Истовремено је постало немогуће артикулисати политику која би била истовремено интернационалистичка и антиелитистичка, јер таква врста политике обично подразумева изразиту мобилизацију класа и антикапиталистичке циљеве.

Исте врсте подела појавиле су се у сфери културе, што доказује и подела између Гуче и Еīзитй (Grabuschnig, 2015). Гуча је постала један од најважнијих модерних елемената у очувању српске националне митологије, јер негује трубу и облике забаве карактеристичне за рурално српско окружење (Kuligovski, 2011). Eīзū̄ је у почетку био комад у широком арсеналу оружја којим се служио покрет Отпор у покушају да се Милошевић сруши. Иако је постојала значајна популарна подршка покрету, нема сумње да је био обухваћен елитистичком, прозападном логиком и као таквог су га подржале и фаворизовале западне владе и невладине организације (Naumović, 2006). Иако је рок сцена са ентузијазмом подржавала демонстрације покрета Отпор, звезде фолк музике остале су посвећене Гучи. Хип-хоп је имао одређену везу са Еїзитиом, нарочито почетком двехиљадитих јер је Еїзий омогућио српској публици да уживо види мегазвезде као што су Cypress Hill или Snoop Dog. Међутим, велики део хип-хоп публике је такође отишао у Гучу, док многи нису били посебно заинтересовани за било који од ова два фестивала.

Друга линија раздвајања у српском друштву срушила се заједно са Милошевићевим режимом. Након 2000. године, тренерке, Air Max патике и евроденс музика нестали су са улица и из медија. Међутим, сви ови симболи задржани су у српској култури, али са префиксом ауре деведесетих година. Хип-хоп супкултура постала је бојно поље истих друштвених и културних подела.

Дизел-супкултура представљала је израз обесправљеног стратума урбане радничке класе који није могао да нађе место на политичкој сцени Србије и Југославије барем од седамдесетих година (Шійа значи срйски национализам, 2011). С нестанком дизел супкултуре као такве, након 2000. године дошло је до захтева за новим културним изразом који би говорио у име овог друштвеног слоја. Хип-хоп се појавио као једини кандидат за ту позицију, а све поделе које су се јавиле у хип-хопу после тога могу се тумачити као ланчана реакција на импозантно присуство gизелашкоі наслеђа.

У остатку овог рада биће показано да је потреба да се заузме став према дизел-култури или gизелашком наслеђу значајно фигурирала у формирању две струје у хип-хопу, које су паралелне с политичким и идеолошким поделама у српском друштву после 2000. године.

Прво, вреди показати како се пејзаж хип-хоп супкултуре лако мапира ко-ристећи исте координате које су створиле поделе на политичкој сцени у првој деценији 21. века. 
Кључне поделе на политичкој сцени биле су садржане у односу према српском национализму и ставу према друштвеној хијерархији. Ова двосмерна подела ствара суштински четири главна политичка положаја у српском политичком спектру. Постоје партије које се могу описати као националистичке, либералне или националистичке, елитистичке с пратећим интелектуалним наративом који гледа на распад комунизма као на позитиван развој догађаја за српску нацију. Међутим, аргумент је да се Србија налази под владавином компрадора и да се суочава с моралном декаденцијом великог дела својих младих људи под утицајем страних, потрошачких медија и декадентних домаћих емитера као што је РТВ Пинк (cf. Antonić, 2010, 2013, inter alia).

Велики део хип-хоп сцене у Србији види хип-хоп као начин да артикулише став урбаних, патриотски оријентисаних младих људи против корумпиране политичке класе лојалне Западу. Најбољи пример је свакако Беоіраgски синgикай (БС). Овај бенд састоји се од младих људи из београдске средње класе који су образовани и који имају успешне каријере као адвокати, економисти, новинари и сл. У погледу социо-економског оквира и по својим текстовима, БС представља националистичке, елитистичке погледе које на политичкој сцени представља ДСС.

Инсистирање на потреби оживљавања елитне културе које долази од конзервативних политичара манифестује се у текстовима БС-а кроз везу са културом старих београдских кафића4 ${ }^{4}$ У песми под називом „Балада дисидента“ налазе се препознатљиве топонимске референце, као што је „Златни бокал“ у Скадарлији, које су типичне за БС и имају јасну сврху повезивања порекла и дела овог бенда са елитним локацијама у Београду (Beogradski sindikat, 2012).

С друге стране, текстови групе БС садрже јасан став према српској политичкој елити лојалној Западу. БС види владајућу политичку елиту као компрадоре или западне лутке који спроводе политику у интересу страних мултинационалних компанија и против српског народа. У песми под насловом „Систем вас лаже“ једна од главних тема јесте идеја да српске власти газе по сопственом народу у интересу страних сила (Beogradski sindikat, 2016).

БС није имун на традиционалну метафору крви и земље која припада крајњој десници. Песме овог бенда повезују веру, нацију, националну државу и државну територију у наводно природну целину. У песми „Нико не може да зна“, српска национална идеја повезана је с вером и територијом која је осигурана у ратовима, али су такође присутне типичне биолошке метафоре као што је веза између земље и мајке (Beogradski sindikat, 2011).

БС има изразито негативан став према наслеђу југословенског социјализма који сматрају једним од узрока садашње ситуације у земљи. У песми „Систем те лаже“ постоји опис социјалистичког система као преваре у којој су људи храњени егалитарном идеологијом, али стварни исход је био богаћење партијског руководства (Beogradski sindikat, 2016).

Као и српска политичка сцена, хип-хоп култура такође има истакнуто либерално крило. Иако је њихова популарност у овом тренутку прилично ниска, либералне снаге традиционално подржава велики део интелектуалне елите, друштвеног слоја који се често назива Друга Србија (Čolović \& Mimica, 1992). Као и конзерва-

${ }^{4}$ Тачније, култура кафића у Београду потиче још из османског доба и разликује се од сличних тенденција на западу пре свега због својих оријенталних конотација (види Hofman, 2010). 
Предраг С. Ковачевић, Између Прве и Друге Србије: о политичкој и класној...

тивци, Друга Србија има свој идеолошки наратив. С обзиром на то да је њихова база готово искључиво средња класа, Друга Србија показује експлицитно елитистичке особине.

Експоненти Друге Србије дубоко су свесни свог недостатка популарности и статуса мањине, због чега опсадни менталитет и осећај да су погрешно схваћени или саботирани од стране заосталих маса играју пресудну улогу у том наративу (види Perović, 2016a, 2016b). Упркос чињеници да ће Друга Србија често кривити масе због опседнутости националним митовима, они се ослањају на још један скуп митова који се ретко испитују и често узимају као крајња истина (Šljukić, 2011). Главна метафора Друге Србије је о нежељеној или крхкој елити коју је изнела Латинка Перовић (2016a, 2016b, inter alia). Она тврди да је заостало српско друштво заслепљено егалитаризмом, колективизмом и везивањем према Русији одувек било непријатељски расположено према рационалним, либералним, прозападним реформаторима. Богдановић (2016), међутим, показује како је овај поглед ближи миту него озбиљној историографији.

Већ је речено да је хип-хоп супкултура ушла у Србију кроз друштвено-економске кругове који су прилично близу Другој Србији. Међутим, после 2000. године, либерални ставови су постали све непопуларнији у хип-хопу. Из тог разлога нема пуно уметника који би могли бити неспорно класификовани као либерали, али има неколико особа чији текстови подржавају основне елементе либералне идеологије. Заједничка тема за све ове уметнике је либерални елитистички став према српском народу који је политички и културно оптерећен националним митовима, фолк музиком и дизел-културом.

Један од најбољих примера ових тенденција је Марко Шелић познатији као Марчело. Као и чланови групе БС, он је стекао и универзитетску диплому и објавио неколико романа и стрипова (Džodan, 2015). Брзо је постао познат због својих лирских способности. Од самог почетка, међутим, многи су сматрали његову вербалну разметљивост и елоквентност арогантном. Марчелов одговор је обично био дистанцирање од таквих слушалаца хип-хопа, често наводећи да себе не сматра репером (Džodan, 2015). Ове теме су прилично истакнуте у песми под насловом „Тестамент“, где наводи да он није репер и да нема никакве везе са сценом (Marčelo, 2008).

Он је један од оних репера који често освајају лаке поене тако што исмевају guзелаше и оне који слушају фолк музику. Суштински десничарски поглед који подрива либералну идеологију очигледан је у Марчеловој употреби исте метафоре болести коју националисти користе када говоре о guзелашкој и фолк супкултури. Међутим, у његовом случају, метафора вируса или болести шири се само међу онима који слушају фолк музику. Марчело (2013) такође подразумева да сви репери деле његово гађење евроденсом.

За разлику од БС-а који покушава да оживи митологију националистичке кафанске елите, Марчело се представља као наследник авангардне уметничке елите окупљене око рокенрола седамдесетих и осамдесетих година. У песми „Позериште“ закључује са упозорењем: „Ако је рокенрол мртав, причамо о самоубиству.“ Импликација је да напуштање традиције рокенрола подразумева нестајање било какве наде за бољу будућност. 
У Марчеловим песмама, српски национализам и политички конзервативизам такође су веома критиковани, али из урбане универзалистичке перспективе (Simić, 2010). На свом првом албуму, у песми под називом „Сузе“, он представља национализам као назадну идеологију која Балкану није донела ништа осим крвопролића.

У супротности са ове две струје у хип-хоп супкултури појављује се антиелитистичко лице хип-хопа које себе види наследником gизелашкої наслеђа. Недостатак образовања, криминалитет, алкохолизам, наркоманија и улична школа су међу особинама које репери, припадници ове струје, сматрају блиским себи. У политичком смислу, већина њих осцилира између екстремне деснице и крајње левице, али је политичка константа за све њих антиелитизам и антилиберализам који се манифестује у идеји о gизелашком начину живота.

Познати хип-хоп бенд, “V.I.P.”, 2000. године издао је албум „Екипа стигла“, који се обично сматра темељем нове генерације хип-хоп супкултуре (Vukčević, 2008). Као што наводи Вукчевић (2008), најважнији потез који је “V.I.P.” учинио је да створи везу између српског идентитета, gизел идентитета и хип-хоп идентитета. Српски идентитет како га је разумео “V.I.P.” је у суштини љута реакција на начин на који се новонастала либерална елита односи према радничкој класи, урбаној омладини. Један од двојице чланова групе “V.I.P.”, Икац, објавио је врло занимљиву песму под називом „Расут у комаде“, где је исказао емоционалну личну перспективу осуђујући сукобе деведесетих година прошлог века, без последичних оптужби за националну издају и припадност Друі̄oj Cрбијu (Ikac, 2010). Међутим, ове тврдње се редовно равнају према Марчелу и осталим реперима који припадају елитистичкој струји.

Још један репер, Ђус, отишао је најдаље је у свесном промишљању могућности повезивања дизел супкултуре и других супкултурних струја које су постојале у Београду, а које су касније класно подељене. Ђус разуме да је елитизам одлучујућа варијабла која је трајно стигматизовала дизел супкултуру чиме је успостављена трајна подела међу младима (Juice vs Moskri, 2011).

Понекад се у први план стављају референце на дизел-културу и систематски се наглашавају, што је случај са Ђусом чија се група зове “93 Фу”, где број 93 представља референцу на 1993. годину - годину злогласне хиперинфлације у Југославији. Његова одећа увек укључује елементе gизелашкоі стила као што су тренерке, златан ланац, Nike патике, итд. Његови текстови су испуњени метафорама и симболима деведесетих. Сврха овог шљаштавог и одбојног стила и имиџа је у великој мери дистанцирање од оних „меких“ и самозаљубљених репера који се, према његовим речима, „понашају као да су андерграунд“.

Групе попут “Прти Бее Гее”, познате по својим експлицитним римама чија се тематика врти око дроге, секса и криминала, најчешће сигнализују њихову припадност дизел-култури честим цитатима евроденс хитова, референцама на познате брендове обуће и одеће популарне деведесетих година и познате личности из дизел-супкултуре. Бенд обично прозива јавне личности које су познате као симболи лажног урбаног морала и елитизма. Лидер ЛДП-а, Чедомир Јовановић, можда је најчешћи циљ критичних и ироничних коментара овог бенда, у којима се наглашава његова веза са криминалним круговима и тешким дрогама што је у супротности са његовим елитистичким јавним имиџом. 
Предраг С. Ковачевић, Између Прве и Друге Србије: о политичкој и класној...

Када причају о боемима са Скадарлије, баш као када се позивају на звезде рокенрола осамдесетих година, чланови групе “Прти Бее Гее” покушавају да их прикажу као сличне себи, а “веза” је обично наркоманија или алкохолизам. У једној песми, покојни вођа бенда, Москри, забавља чланове бенда "Електрични оргазам" и сугерише да су зависници попут њега (Prti Bee Gee, 2012). У још једној песми, он се пореди са Драгомиром Бојанићем Гидром, легендарним глумцем и боемом, овог пута на основу зависности од алкохола (Prti Bee Gee, 2013). Москријева сатира се често артикулише егалитарним ставом кроз представљање елите као обичних људи, при чему припаднике елите пореди са самим собом.

“Прти Бее Гее” говори о стварности свакодневног живота зависника који чине растући део урбаног становништва. Међутим, оно што је можда још интересантније је начин на који је овај бенд успео да отвори простор за артикулацију гласова ромске популације. Либерални кругови често инсистирају на позитивним стереотипима када је у питању ромска популација, као што су њихове музичке способности. Још од Саидовог (2004) модерног класика под насловом “Оријентализам”, познато је да управо такви позитивни стереотипи представљају конститутивни елемент расизма који ради на легитимизацији језгра расистичке логике. С друге стране, истина је да су криминал, сиромаштво и зависност део свакодневног живота већине Рома у Србији.

Члан групе “Прти Бее Гее”, Никола Јелић, познатији под псеудонимом Микри Маус, који потиче из ромске породичне средине, стално се позива на паралелизам између афроамеричке популације у Америци и Рома и gизелаша у Србији. За Микри Мауса, чињеница да се Роми често обраћају једни другима користећи реч Циіанин директни је пандан речи uрна (енг. nigger) коју користе Афроамериканци стихови рутински укључују кратке, хумористичке анегдоте из свакодневног живота Рома у радничком насељу Медаковић у Београду и оближњем делом неформалном насељу познатом као Маринкова бара. Текстови групе “Прти Бее Гее” чине овај живи друштвени миље ближим остатку урбаног друштва Србије. У новијим радовима групе “Прти Бее Гее” и соло пројектима Микри Мауса, референце на Роме и guзелаше постале су један од главних начина подривања доминантне, елитистичке и либералне идеологије (Mikri Maus, 2015).

Оно што се може схватити као левичарски антиелитизам често се поклапа са идејама екстремне деснице на истом путу. Добар пример екстремне десничарске визије хип-хопа као наследника дизел-културе је млади репер познат као Марлон Брутал. Његова идеологија и реторика су добро илустроване у песми под називом „Булевар насиља“. Његове риме у овој песми представљају моћан опис атмосфере у београдским радничким насељима где је мирис марихуане и насиља интегрални део детињства и адолесценције (THCF \& Marlon Brutal, 2009). Ocновна идеолошка линија је она о безусловној солидарности са „ортацима“ и ду-

\footnotetext{
${ }^{5}$ Кенеди (2008) је покушао, углавном путем белих либерала, да легално забрани коришћење такве речи белим и црним људима подједнако. Према Кенедију (2008), за Афроамериканце ова реч представља моћну политичку, културну и историјску везу и облик политичке мобилизације на симболичком нивоу. Покушај либерала да забране ову реч представља само један илустративан пример пројекта универзалне пацификације под шаком политичке коректности.
} 
бока мржња према свима који не припадају том друштвеном миљеу - људима из других делова града или из других градова, љубитељима различитих спортских клубова или људима из других земаља. Важно је напоменути да су овде дизел култура и фолк музика дефинишуће културне особине јер припадање култури радничке класе насупрот елитној култури представља централни елемент идентитета припадности крају.

Иако Марлон Брутал сматра да су лаки и синтетички лекови уједно и саставни део онога што представља свакодневни живот у крају, он изражава изразиту мржњу према тешким дрогама. У десничарским круговима где су физичка снага и способност ангажовања у насиљу од велике важности, тешке дроге се скоро увек посматрају као зло, а корисници дрога се виде као људски паразити.

Антиелитистички репери често исмевају или директно вређају репере из елитистичког (либералног и националистичког) дела хип-хоп сцене, док је обрнута ситуација редак случај. Групе попут “Прти Бее Гее” су практично недодирљиве за критику барем међу посвећеним љубитељима хип-хопа, упркос њиховом глорификовању злочина и зависности, што људи изван хип-хоп кругова често критикују. Њихов статус је додатно зацементиран након смрти најистакнутијег члана Москрија, који је постао митска фигура на хип-хоп сцени и често се упоређује са легендарним Тупак Шакуром (видети Keeling, 1999, о митском статусу Тупак Шакура).

\section{5. Закључак}

На крају, треба рећи да је значење класних подела унутар хип-хоп супкултуре анализирано у контексту успона екстремне деснице и слабости радикалне левице у садашњој Србији, како је описао Бакић (2015) поред многих других. Исход ове нестабилне ситуације битно ће зависити од опште политичке климе и можда способности левичарских снага да превладају академизам, елитизам и интелектуализам који тренутно дефинше већину левичарских организација.

\section{REFERENCES / ЛИTЕРATУРA}

\section{Primary sources/ Примарни извори}

24sata. (2013, February 9). A panel on the revolution of (Serbian) rap and urban youth cultures. Retrieved January 03, 2017, from http://arhiva.24sata.rs/scena/muzika/ vest/o-revoluciji-srpskog-repa-i-urbanim-kulturama-mladih-na-tribini-dob/ print/75596.phtml [in Serbian]

Beogradski sindikat. (2011, January 11). No one can know. Retrieved November 06, 2017, from https://www.youtube.com/watch?v=H0ZyNvxc-60 [in Serbian]

Beogradski sindikat. (2012, April 06). A Dissident's Ballad. Retrieved October 24, 2017, from https://www.youtube.com/watch?v=1W0L-v2NlRk[in Serbian]

Beogradski sindikat. (2016, April 19). The System is Lying to You. Retrieved October 24, 2017, from https://www.youtube.com/watch?v=hkSzmPnzF-o [in Serbian] 
Предраг С. Ковачевић, Између Прве и Друге Србије: о политичкој и класној...

Ikac. (2010, February 18). Blown Away into Pieces. Retrieved October 24, 2017, from https://www.youtube.com/watch?v=MP5Xkdho30M

Juice \& Monogamiia (2008. Inne 26) Ganghang 1 Retrieved October 24, 2017, from https://www.youtube.com/watch?v=XZf3fmlJswM][in Serbian]

Marčelo, T. (2008, December 21). Testament. Retrieved October 24, 2017, from https:// www.youtube.com/watch?v=ftQWCrd4Qkg [in Serbian]

Marcelo. (2013, November 01). Imposter theater. Retrieved October 24, 2017, from https://www.youtube.com/watch?v=y2TeZaF4J61 [in Serbian]

Mikri Maus. (2015, March 19). Original Gypsy. Retrieved October 24, 2017, from https:/] www.youtube.com/watch?v=OghpBpDF9Vs [in Serbian]

Prti Bee Gee. (2012, April 07). Leto. Retrieved October 24, 2017, from https://www. youtube.com/watch?v=O6PD6hmwlvE [in Serbian]

Prti Bee Gee. (2013, February 02). Praise Sweet Crack. Retrieved October 24, 2017, from https://www.youtube.com/watch?v=IIwBqhxi7jU][in Serbian]

Robin Hood. (2012, January 30). Gangster. Retrieved October 24, 2017, from https:/ www.youtube.com/watch?v=uHHGYnL7B5U][in Serbian]

THCF \& Marlon Brutal. (2009, September 02). A Boulevard of Violence. Retrieved October 24, 2017, from https://www.youtube.com/watch?v=JCfE0JWx1CU] [in Serbian]

Džodan, N. (2015, May 28). Marčelo: I Am Not Only a Rapper, I Won’t Hand My Music Over to the Politicians. Retrieved January 03, 2017, from/http://www.blic.rs/zabava vesti/marcelo-nisam-samo-reper-ne-dam-moju-muziku-politicarima/7lredwc [in Serbian]

\section{Secondary sources/ Секундарни извори}

Ambrozić, D. (1994). Black rain will fall.. Ritam, 4, 48-49. [In Serbian]

Antonić, S. (2010). Compradores. Pečat, Beograd, 109, 9-9. [In Serbian]

Antonic, S. (2013). Pink transition in Serbia: Six theses concerning our cultural situation. Kultura, 140, 272-292. doi:10.5937/kultura1340272a [In Serbian]

Baker, C. (2008). When Seve Met Bregović: Folklore, Turbofolk and the Boundaries of Croatian Musical Identity. Nationalities Papers, 36(4), 741-764. doi:10.1080/00905990802230514

Bakic, J. (2015). Left and right: A theoretical definition and its empirical application in the case of Serbia (1990-2014). Sociologija, 57(1), 46-71. doi:10.2298/soc1501046b [In Serbian]

Bogdanović, M. (2016). Elitist Solitaire: Latinka Perović 's Historical Revisionism. Beograd: Mostart. [In Serbian]

Bolcic, S. (2003). Blocked Transition and Post-Socialist Transformation: Serbia in the Nineties. Review of Sociology, 9(2), 27-49. doi:10.1556/revsoc.9.2003.2.2

Canton, D.A. (2006). The Political, Economic, Social, and Cultural Tensions in Gangsta Rap. Reviews in American History, 34(2), 244-257. doi:10.1353/rah.2006.0021

Chang, J. (2005). Can't Stop Won't Stop: A History of the Hip-Hop Generation. New York: Picador.

Čolović, I., \& Mimica, A. (1992). The Second Serbia. Beograd: Borba. [In Serbian]

Dyson, M.E. (1996). Between God and Gangsta Rap: Bearing Witness to Black Culture. New York: Oxford University Press. 
Grabuschnig, R. (2015). More than one Serbia?, The nationalisation of cultural space on the example of the Guča trumpet festival. Central European University. Unpublished Master of Arts Thesis Budapest: Available at www.etd.ceu.hu/2015/grabuschnig_ralf.pdf

Gordy, E.D. (2010). Culture of Power in Serbia: Nationalism and the Destruction of Alternatives. Penn State University Press.

Hall, S. (1980). Cultural studies: two paradigms. Media, Culture \& Society, 2(1), 57-72. doi:10.1177/016344378000200106

Hebdige, D. (1979). Subculture: The meaning of style. London: Methuen.

Hip-hop as the local newsletter of the Serbian working class (part II) (2013) Available at teorijaizteretane.blogspot.rs/2013/02/hip-hop-kao-lokalno-glasilo-srpske 16.html

Hofman, A. (2010). Kafana singers: Popular music, gender and subjectivity in the cultural space of socialist Yugoslavia. Narodna umjetnost-Hrvatski časopis za etnologiju $i$ folkloristiku, 47(1), 141-161.

Janjatović, P. (2007). Ex-Yu Rock Encyclopedia. Beograd: Čigoja štampa. [In Serbian]

Jansen, S. (2005). Who's afraid of white socks?, Towards a critical understanding of postYugoslav urban self-perceptions. Ethnologia Balkanica, 9, 151-167.

Jones, O. (2011). Chavs: The demonization of the working class. London: Verso.

Juice vs Moskri: Leaders of the generation (2011) Available at http://dizelgorivo.blogspot. rs/2011/05/juice-vs-moskri-predvodnici-generacije.html[In Serbian]

Keeling, K. (1999). "A Homegrown Revolutionary"?: Tupac Shakur and the Legacy of the Black Panther Party. The Black Scholar, 29(2-3), 59-63. doi:10.1080/00064246.1999 11430964

Kennedy, R. (2008). Nigger: The strange career of a troublesome word. New York: Vintage.

Kuligovski, V. (2011). Normal People`s Nationalism. Ethnicitization Of Music Tradition On Festival In Guča. Antropologija, 11(1),

Maffesoli, M. (1991). The times of the tribes. London: Sage.

Matić, Đ. (2005). Đogani Hamed. In I. Andrić \& et al. (Eds.), Leksikon YU Mitologije. Belgrade: Rende.

Musić, G., \& Vukčević, P. (2017). Diesel Power: Serbian Hip Hop from the Pleasure of Privileged to Mass Youth Culture. In M. Miszczynski \& A. Helbig (Eds.), Hip Hop at Europe's Edge: Music, Agency, and Social Change. (pp. 85-108). JSTOR. doi:10.2307/j ctt2005sm8.9

Naumović, S. (2006). "Otpor"- A Postmodern Faust: New Social Movement, the Tradition of Enlightened Reformism and the Electoral Revolution in Serbia. Filozofija $i$ društvo, 31, 147-194. Available at http://instifdt.bg.ac.rs/wp-content/ uploads/2015/05/S.Naumovic-3-2006.pdf [In Serbian]

Papovic, J., \& Pejovic, A. (2016). Revival without Nostalgia: The 'Dizel' Movement, Serbian 1990s Cultural Trauma and Globalised Youth Cultures. In M. Schwartz \& H. Winkel (Eds.), Eastern European Youth Cultures in a Global Context. (pp. 81-93). London: Springer Nature America, Inc. doi:10.1057/9781137385130_5

Perović, L. (2016). Serbian Russian Historical Analogies. In S. Biserko (Ed.), The Warp of the Serbian Identity. Beograd: Helsinški odbor za ljudska prava u Srbiji, 57-83. Available at https://www.helsinki.org.rs/serbian/doc/Ogledi17.pdf In Serbian]

Perović, L. (2016). Dominant and unwanted elite. Beograd: Dan Graf. [In Serbian]

Ro, R. (1996). Gangsta: Merchandizing the rhymes of violence. New York: St Martin's Press. Said, E.W. (2004). Orientalism. New York: Vintage Books. 
Предраг С. Ковачевић, Између Прве и Друге Србије: о политичкој и класној...

Simić, M. (2010). Locating Cosmopolitanism: Practicing Popular Culture in Post-socialist Serbia. Der Donauraum, 50(3-4), 345-365 doi:10.7767/dnrm.2010.50.34.345

Šljukić, S. (2011). Myth as Destiny. Sremski Karlovci: Kairos. [In Serbian]

What does Serbian nationalism mean in the domestic music of the street - from Belgrade Syndicate Band to Monogamy and Marlon Brutal (2011). Available at http:// dizelgorivo.blogspot.rs/2011/06/sta-znaci-srpski-nacionalizam-u-domacoj.html [In Serbian]

Vukčević, P. (2008). Young (and healthy) as rap. Available at http://www.popboks.com/ article/7016 [In Serbian]

Žižek, S. (2008). Violence: Six sideways reflections. London: Profile Books. 